\title{
Tectonic Geomorphology of Iran's Salt Structures
}

\author{
Mehran Arian', Hamideh Noroozpour ${ }^{2}$ \\ ${ }^{1}$ Department of Geology, Science and Research Branch, Islamic Azad University, Tehran, Iran \\ ${ }^{2}$ Department of Geology, Faculty of Science, Payame Noor University, Tehran, Iran \\ Email: mehranarian@yahoo.com
}

Received 13 January 2015; accepted 9 February 2015; published 13 February 2015

Copyright (C) 2015 by authors and Scientific Research Publishing Inc.

This work is licensed under the Creative Commons Attribution International License (CC BY).

http://creativecommons.org/licenses/by/4.0/

(c) (i) Open Access

\begin{abstract}
Iran has a various salt structures that their tectonic geomorphology is subject of this paper. Geologic situation of salt structures in Iran have determinate. According to age and geological setting of salt deposits that revealed by tectonic geomorphology methods, salt structure provinces of the Central and Southern Iran have been distinguished. Also, critical concepts of salt diapirism in the Southern Iran and Central Iran salt basins have explained. Therefore, Central Iran's salt diapirs have triggered by tectonic forces, but salt diapirism in the Southern Iran has triggered by halokinesis, then it has effected by tectonic forces, especially in Zagros fold and thrust belt.
\end{abstract}

\section{Keywords}

\section{Tectonic Geomorphology, Salt Structures, Diapir, Iran, Halokinesis}

\section{Introduction}

Tectonic geomorphology is the study of the interaction between tectonics and surface processes that form the structure during geologic times. Salt diapir or piercement structure with a central, nearly equidimensional salt plug, generally one to two kilometers or more in diameter, which has risen through the enclosing sediments from a mother salt bed beneath the top of the plug, is called salt dome [1]. For the first time, the economic importance of salt domes was expressed at the beginning of the recent century, when discovery of oil and gas had developed, because oil and gas are trapped around and under the some salt domes. About four fifth of oil and gas, which is reserved at south of united state of America as well as some oil reserves in the middle east, are in some way affiliated to the salt structure. In addition, extracted crude oil and natural gas are mostly preserved at salt caves, for future use. Meanwhile, due to non-permeable character of salt, it has been suggested to store radioactive wastes in the salt crevasses [2]. The main aim in this paper is determination of diapiric provinces in Iran. Iran has com- 
posed from different plates. Arabian plate in south and west (Zagros and Persian Gulf), Cimmerian miniplate in north and east, Eurasian plate in northeast margin [3] and [4]. There are three physiographic-tectonic zones that they have salt diapirs: 1) Zagros Mountain; 2) Persian Gulf basin; and 3) Cental Iran basin.

\section{Geologic Setting}

\subsection{Zagros Mountain}

Dominant structural trends in Zagros Mountain (Figure 1) are NW-SE in northwestern part and E-W in southeastern part. From tectonics point of view, it contains the overthrusted and simple folded belts of Zagros that formed on the northeastern part of Arabian plate's passive margin. Zagros is external platform (folded and thrusted belt) of north margin of Arabian Craton. Vergence of folding in this zone is toward south and southwest. Hormuz Salt had been deposited within main sub-basins of Zagros basin in Late Precambrian-Early Cambrian. The Hormuz formation is formed by salt, anhydrite, black dolomite, shale, red siltstone and sandstone and volcanic rocks. The most of 107 emergent salt structures are related to central and eastern part Zagros. The Hormuz and equivalent series were deposited in an Evaporite basin during the late Precambrian-early Cambrian [5]. Coeval salt basins crop out in a large domain including the Central Iran as Ravar series [6].

\subsection{Persian Gulf}

Dominant structural trend in Persian Gulf basin (Figure 1) is NW-SE. From tectonics point of view, it contains the south margin of simple folded belts of Zagros that formed on the northeastern part of Arabian plate's passive margin. Persian Gulf is north margin of internal platform of north margin of Arabian Craton and foreland basin of Zagros Mountain.

Hormuz Salt had been deposited within in Persian Gulf basin in Late Precambrian-Early Cambrian. The name of the Hormuz Salt was taken from the Iranian Hormuz Island (Figure 2) cored by a salt diapir, which also gives its name to the opening strait of the Persian Gulf. Eight emergent salt structures or Iranian diapiric islands such as Hormuz, Larak, Tonb-Kochak, Tond-e Bozorg, Abu Musa, Faror, Bani-Faror and two emergent salt structures in Qeshm and Hengam Islands are related to northeastern part of Persian Gulf.

\subsection{Central Iran}

Dominant structural trends in Central Iran (Figure 1) are NW-SE in northwestern part and N-S in eastern part. From tectonics point of view, it contains Iranian plateau. The Iranian plateau is one of the two main plateaus in the Alpine-Himalayan collision system. The basement of the plateau consists of Cimmerian miniplate. Volcanics of Late Cretaceous-Early Miocene age in Central Iran represent Andean type magmatism during Neo-Tethyan subduction [8].

Volcanic rocks, evaporates and turbidites successions up to $3 \mathrm{~km}$ thick represent Eocene back-arc extension across Central Iran. This succession is commonly overlain in Central Iran by terrestrial clastics, evaporates and volcanics of the Lower Red Formation; of Oligocene age [9]. Marine deposition resumed across much of Central Iran with the carbonates of the largely lower Miocene Qom Formation. The Qom Formation is overlain by middle Miocene terrestrial clastics and evaporates of the Upper Red Formation.

The salt deposits belonging to Cenozoic of Central Iran basin have two separate origins: The old type related to Upper Eocene deposits and Lower Red formation; and new type related to Upper Red formation [10]. In the Central Iran basin, there are many salt domes, which as compared with the salt domes of Zagros and Persian Gulf basin, less attention have been paid to them. The reason of this issue, also lays in presence of oil and gas reserves at later cases. Extrusion of Hormuz salt domes of Zagros [11] and Persian Gulf basin are the deeper and older than Central Iran basin [12], [13] and [14].

\section{Diapiric Provinces of Iran}

Salt diapirs of Iran present a large variety of shapes and elevation from high relief to entirely eroded structures. In addition, they have different sizes at outcrop scale, ranging from craters a few km wide to diapirs and glaciers more than $5 \mathrm{~km}$ wide.

These different morphologies are controlled by various factors, for example, position related to other structures, the time of emergence, the rate of salt dissolution, which is controlled by the rate of erosion, the bulk rate 

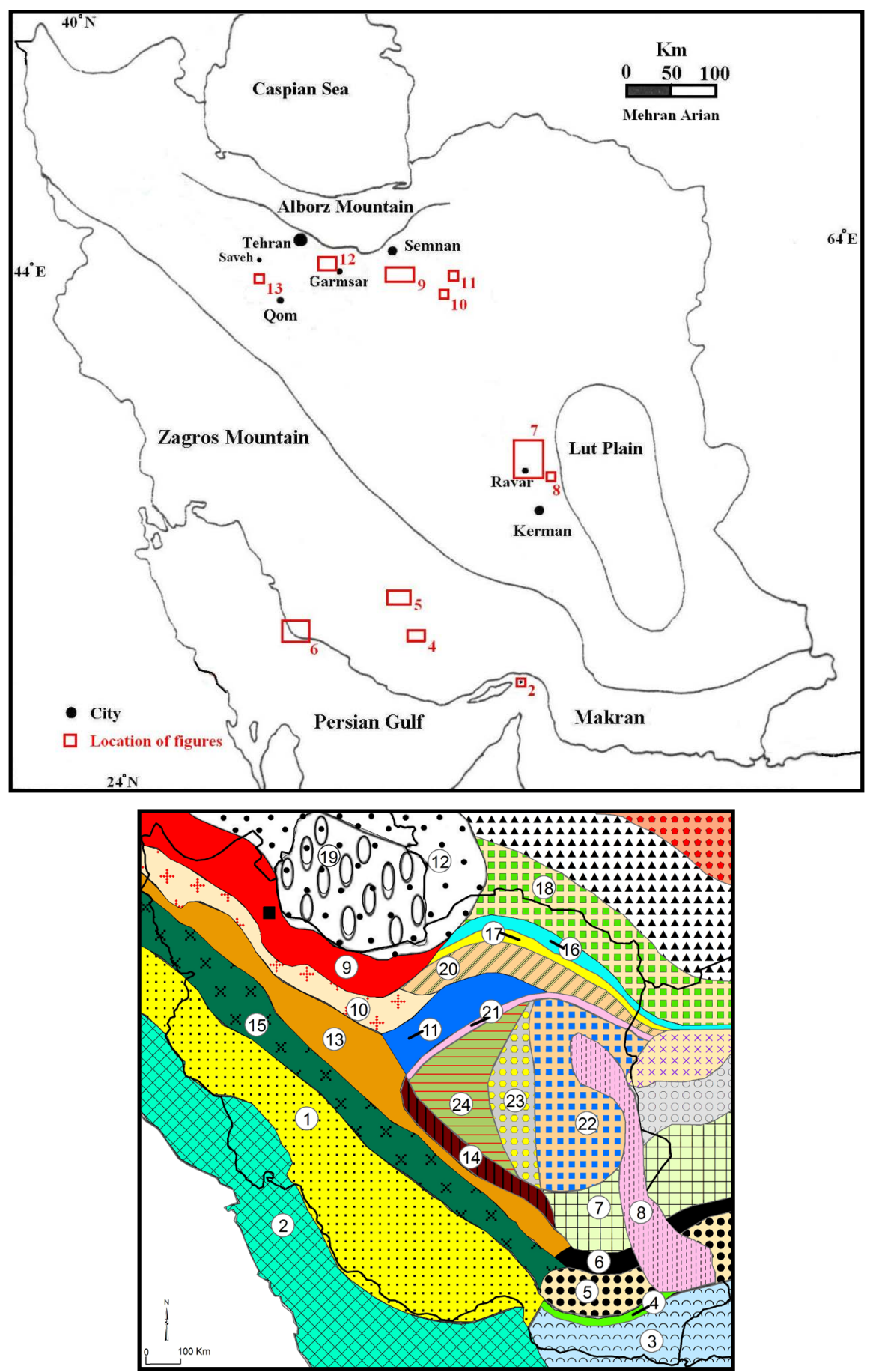

Figure 1. Geographical distribution of salt diapiric areas in Iran. Locations of figures 2, 4 to 13 are shown by red rectangles, grids marked by border of figure (up) and Physiographic-tectonic zoning map of Iran's sedimentary basins Iran (down), modified from [7]. Numbers in this figure are, 1: Zagros-East Taurus hinterland, 2: Persian Gulf-Mesopotamian foreland basin, 3: Makran accretionary prism, 4: Bashagard Mountains, 5: Jazmorian-Mashkel fore arc basin, 6: Shahsavaran-Soltan magmatic arc, 7: South Lut-South Helmand back arc basin, 8: East Iran Mountain belt, 9: West-Central Alborz and lesser Caucasus hinterland, 10: Great Kavir-Northen Urmieh lake foreland basin, 11: South Great Kavirfold and thrust belt, 12: South Caspian-Black Sea foreland basin, 13: Urmieh-Dokhtar magmatic arc, 14: Naien-Kerman retro arc foreland basin, 15: Sanandaj-Sirjanoverthrust belts, 16: East Alborz or Binalod hinterland, 17: Torbat-e am-Neyshabour retro arc foreland basin, 18: Kopet Dagh hinterland, 19: South Caspian remnant basin, 20: Maiamay-Taibad Inverted back arc basin, 21: Khaf-Kavir Plain magmatic arc, 22: Lut Plain-Gonabad back arc basin, 23: Tabas hinterland, 24: Yazd-Khour Piggy back basin. 


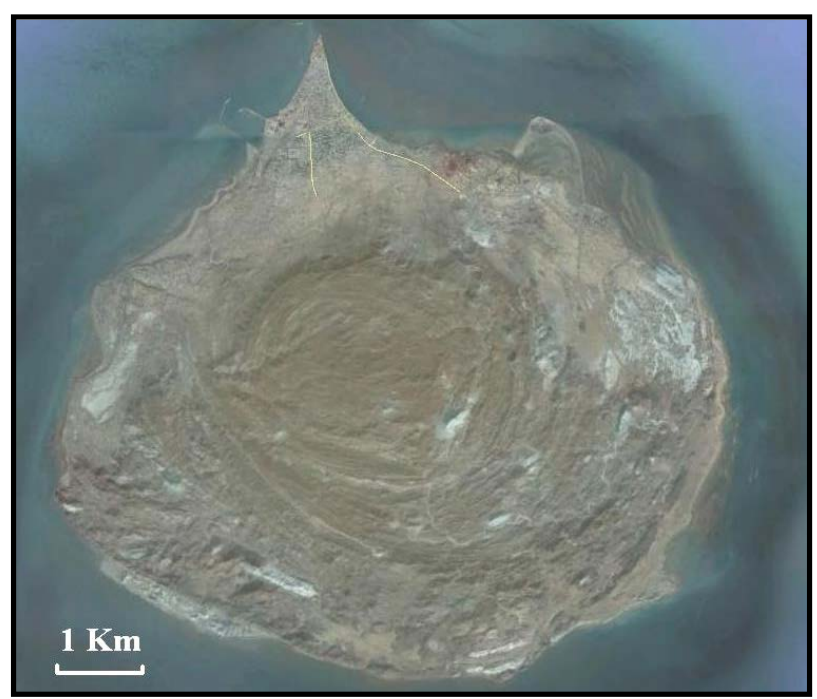

Figure 2. ETM+ satellite image of Hormuz Island in the eastern part of Persian Gulf. Map located in Figure 1.

of salt emission from the source layer, and eventually by the tectonic activity [15]. Based on the previous investigations such as [16] and this research, nine diapiric provinces have distinguished in Iran (Figure 3).

\subsection{Hormuz Province}

Hormuz province (Figure 3) in southeastern part of Zagros, with 84 emergent diapirs can be considered the most extensive salt basin of Zagros. Most of salt domes are pre-orogenic emergent diapirs, and had a prominent role in determining the shape and location of folds during the Zagros orogeny. But, some of the salt diapirs have been located on the plunging noses of anticlines. So, they are post-orogenic emergent diapirs. Also, salt glaciers (Figure 4) are common feature in this diapiric province.

\subsection{Nyriz-Jahrum Province}

Nyriz-Jahrum province (Figure 3) in eastern part of Zagros, with a few emergent diapirs, many blind salt domes such as Sim, Meymand, Bavush, Kharman, Kuh-e Gavbast anticline and diapiric fold such as Kuh-e Bavush and Khaftar anticlines (Figure 5) can be considered as the blind salt basin of Zagros. The Southern part of NyrizJahrum province has been formed by Gavbandi High [17]. An old regional uplift was formed by the Qatar Arc and its northward continuation towards Zagros. Many researchers believe that, Gavbandi High has more height related to around area during the Late Pre Cambrian-Early Cambrian and so, there was very shallow evaporate basin as same as western part of Zagros.

\subsection{Shiraz-Kazerun Province}

Shiraz-Kazerun province (Figure 3) in central part of Zagros, with 23 emergent diapirs can be considered the second most extensive salt basin of Zagros.

Most of the salt diapirs have been located on the main segments of transverse strike slip faults such as Kazerun fault (Figure 6) with 6 salt diapirs, Kareh Bas fault with 6 salt diapirs and Sarvestan fault with 3 salt diapirs. So, most of them are pre-orogenic emergent diapirs, and they had a prominent role in determining the shape and location of folds during the Zagros orogeny. Also, salt glaciers such as Kuh-e Namak (Figure 6) are common feature in this diapiric province.

\subsection{Ravar Province}

Ravar province (Figure 3) with north-south trending is bound to main fault of Nayband at east, and Kalmard at west. The subsidence of this province, during upper Jurassic, can be considered as the cause of evaporate con- 


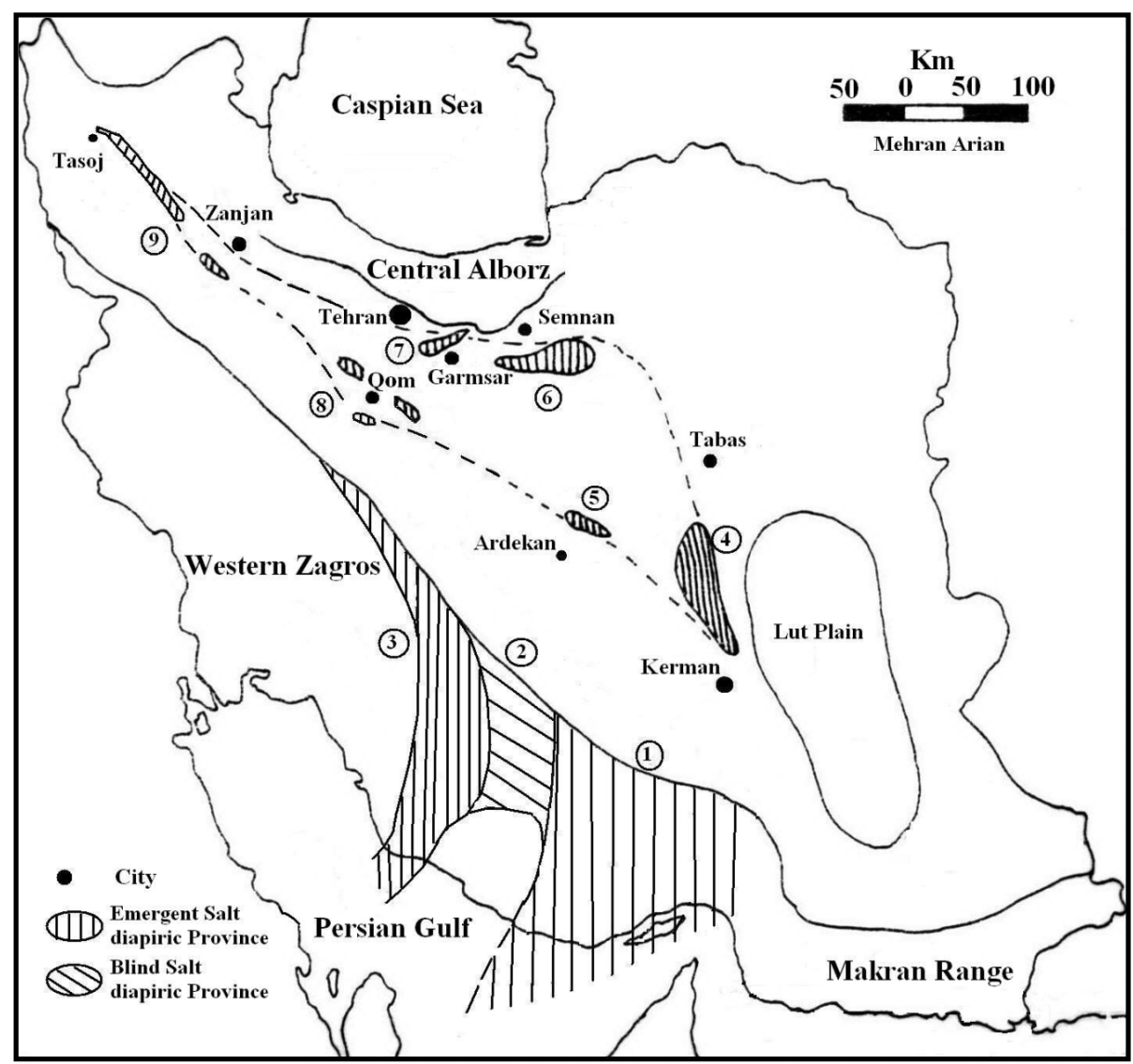

Figure 3. Geographical distribution of diapiric provinces in Iran. Locations of diapiric provinces are shown by numbered circles.

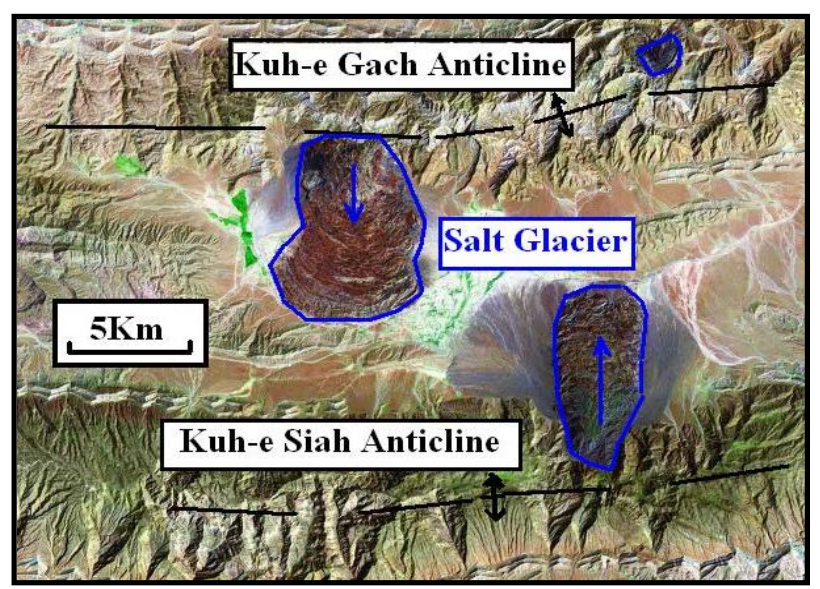

Figure 4. Interpreted ETM+ satellite image of two salt glaciers (blue color) at Hormuz diapiric province, between two anticlines (black color). Map located in Figure 1.

centrations (Mago Group) in it. However, due to regional compression, we are now encountering its additional diapirism. Meanwhile, as the salt domes have projected in a dominant north-south direction, the external trigger impact on the region's diapirism shall be assumed effective [18]-[20].

At this province, there are separate individual salt domes, at a north-south trending faults. The salt domes are related to upper Jurassic salt formation [21] along Ravar fault and diapiric unit of Ravar series along Lakarkuh fault (Figure 7). 


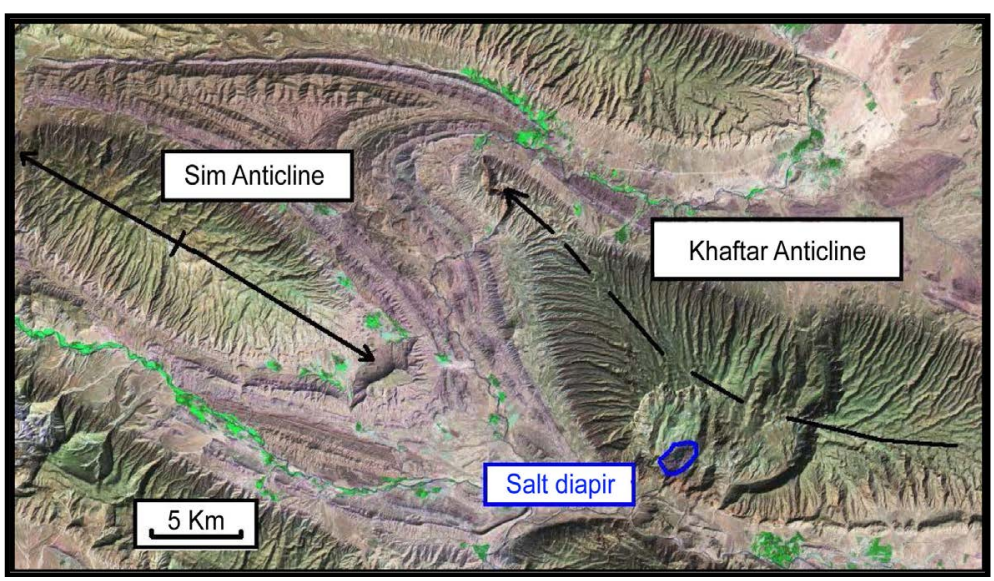

Figure 5. Interpreted ETM+ satellite image of Sim Anticline (a blind salt dome) and Khaftar anticline (a diapiric fold) with a small salt plug (blue color) at Nyriz-Jahrum province. Map located in Figure 1.

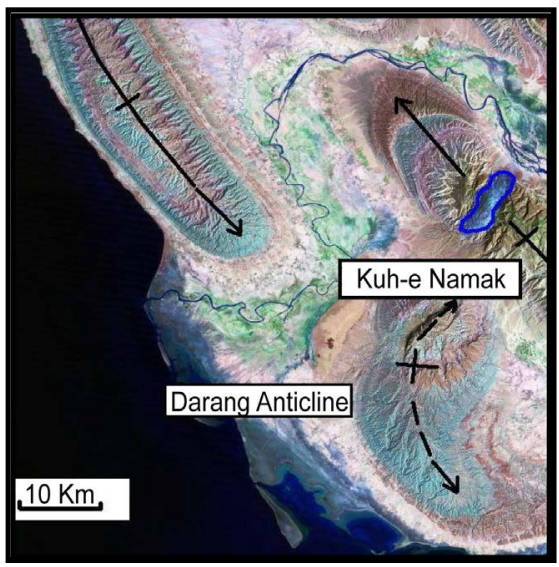

Figure 6. Interpreted ETM+ satellite image of Kuh-e Namak salt glacier (blue color) and Darang Anticline (a diapiric fold) at south of Shiraz-Kazerun province. Map located in Figure 1.

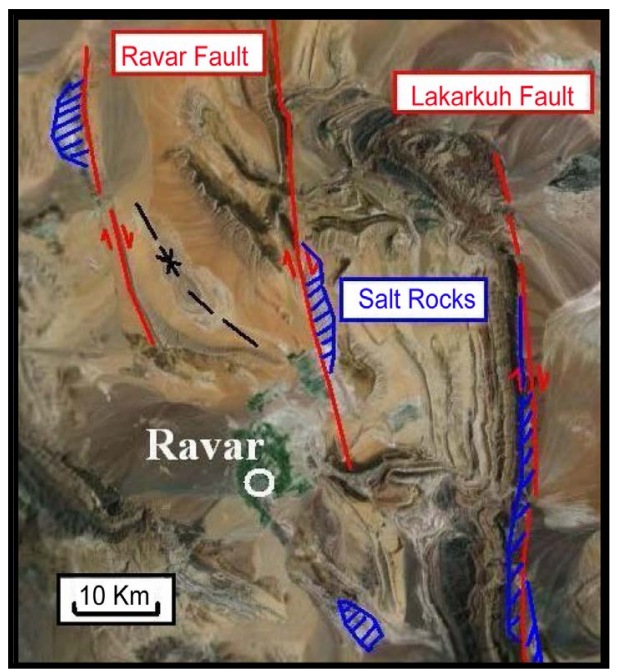

Figure 7. Interpreted ETM+ satellite image of Ravar region and its salt structures (blue color). Map located in Figure 1. 
Also, separated salt glacier (Figure 8) has been cropped out between Nayband and Lakarkuh faults, in extensional trend of resulting shear zone.

\subsection{Kalot Province}

The salts of diapiric province of Kalot basin in northeast of Ardekan (Figure 3) is relate to the Qom basins. So, in this case, this province can be considered as the extent of southeastern part of the Qom diapiric province.

At Kalot region, the salt domes are mostly of oval shape; which at some regions, due to erosion function, are transformed to cabbage form flower. The salts of Kalot province are distinguished to be of old type and the external trigger has confirmed by shape of salt diapirs [22].

\subsection{Great Kavir Province}

Great Kavir province (Figure 3), at south of Semnan can be considered as the most extensive salt basin of Central Iran. Because, based on the previous studies, such as [23] and [24], there are old and new type salt diapirs. Now we encounter penetration of interrelated diapirs with old and new salts—side by side or inside each other.

At this province, more than 50 salt domes are emergent. Erosion has resulted in the formation of 12 side-byside diapirs (Figure 9), whose their appearance is similar to that of a canopy. The salts of this region are of old and new types. So the diapirism of this area can be assumed to have two separate origins. Also, a typical Crescentic folds (Figure 10) and a Vortex mushroom diaper (Figure 11) has been appeared in Great Kavir province.

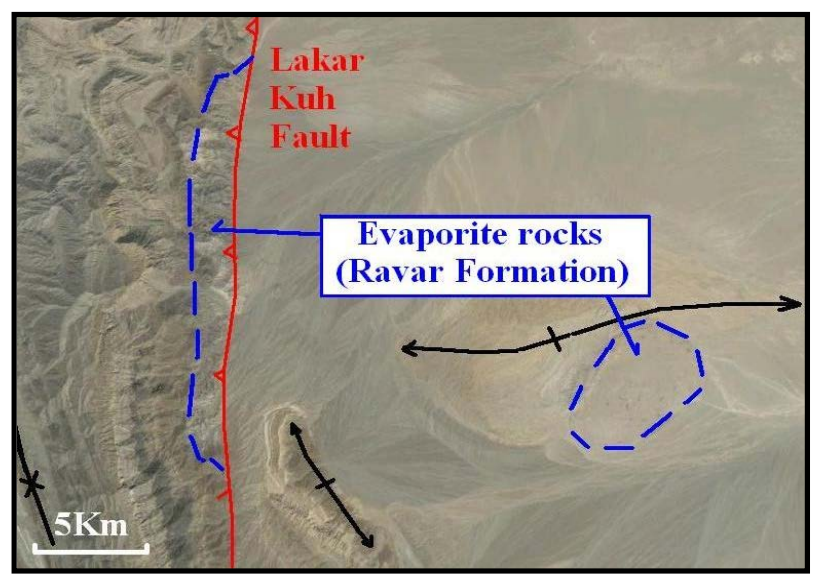

Figure 8. Interpreted ETM+ satellite image of a salt glacier (blue color) in the eastern part of Lakarkuh fault. Map located in Figure 1.

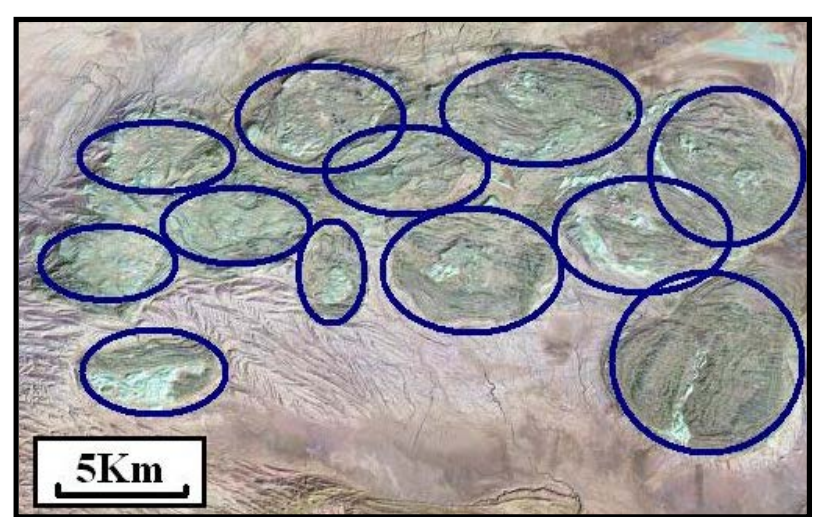

Figure 9. Interpreted ETM+ satellite image of 12 side-by-side salt diapirs (blue color) at south of Semnan. Map located in Figure 1. 


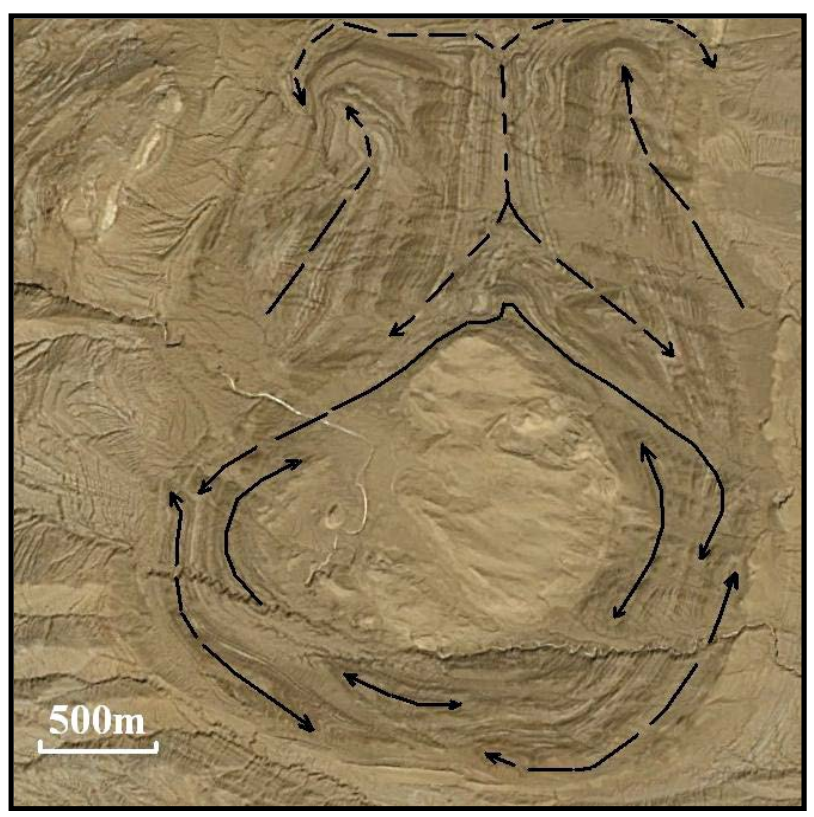

Figure 10. Interpreted ETM+ satellite image of a typical Crescentic folds (black color) at southeast of Semnan. Map located in Figure 1.

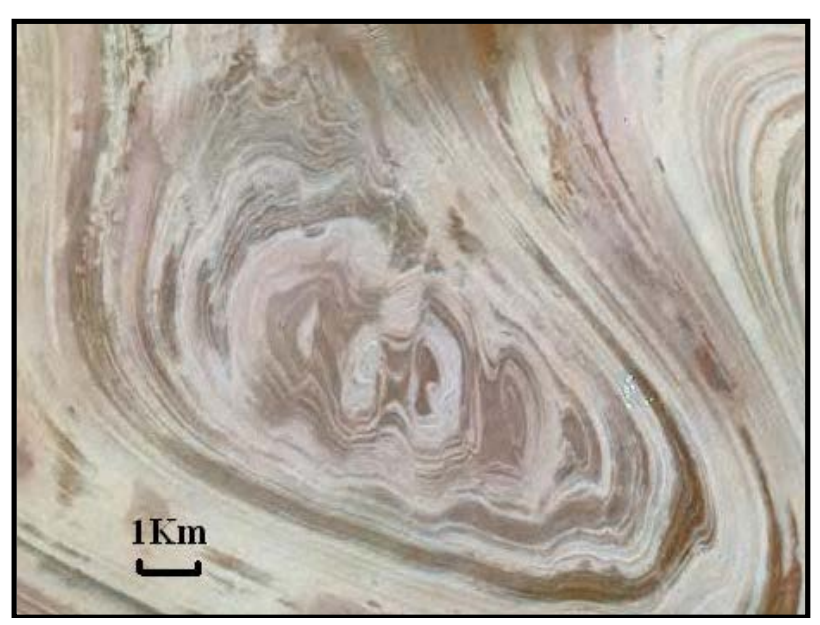

Figure 11. Interpreted ETM+ satellite image of a typical eroded Vortex mushroom diapir at Great Kavir province. Map located in Figure 1.

\subsection{Garmsar Province}

Garmsar province (Figure 3) belongs to depression of northwestern margin of Great Kavir. The salts of this province are of old type, in which presence of salt, gypsum and sulfur reserves has been resulted in increase of mining activities at this area. The origin of Garmsar region salt domes are distinguished as Lower Red formation and external trigger have confirmed by stretch shape of salt dome. There is a salt-tongue canopy with $130 \mathrm{~km}^{2}$ areas that introduced as the biggest salt glacier in Iran (Figure 12) in front of an active region or Central Alborz [25]-[27].

\subsection{Qom Province}

The diapiric province of Qom can be defined as a northwestern-southeastern depression. The maximum longitu- 
dinal extension of this province, is about $200 \mathrm{~km}$, which extends from west of Saveh to south of Qom. The implemented studies indicate, that the salts of this province, are mostly of old type and their limited projections, relate to the presence of main structures at the region. There is a separate individual salt dome (Figure 13), at a relatively extensive plain. According to [28], diapirism of this structure can be assumed to have two separate origins (a combination of old and new type).

\subsection{Zanjan-Tasoj Province}

This province is located from southwest of Zanjan to south of Tasoj (Figure 3). The implemented studies indicate that the salts of this province are of new type that intruded along main faults [29].

\section{Discussion}

Based on [30], three diapiric provinces in the Southern Iran (Zagros and Persian Gulf) that they have concerned to the Hormuz, Nyriz-Jahrum and Shiraz-Kazerun salt basins, are related to the evaporate basins of thin-skinned folded and thrusted belt [31] and [32]. Two diapiric provinces in the Central Iran that they have concerned to the Great Kavir and Garmsar salt basins, are related to the evaporate basins of gravity gliding-related shortening at toe of a continental rift. Other diapiric provinces in the Central Iran that they have concerned to the Ravar, Kalot, Qom and Zanjan-Tasoj salt basins, are related to the evaporate basins of intracratonic inverted basin. Also, main characteristics of salt diapirism in the Southern Iran and Central Iran salt basins have summarized in Table 1.

There are three mother layers in the Southern Iran salt basins. It seems that, salt combination of Hormuz and Dashtak mother layers (Late Triassic) caused to formation of Salt-Wing Intrusion [33] in Zagros and Persian Gulf. Also, thick evaporate Gachsaran formation (Late Miocene), formed a type of Raft Tectonics in Fars Group, especially in the Dezful Embayment. Diapirism process of Gachsaran mother layer is comparable to Upper Red mother layer in the Central Iran salt basins.

\section{Conclusions}

Based on the shape and orientation investigations of salt domes in Iran, nine diapiric provinces have introduced. Six diapiric provinces in Central Iran have concerned to the Ravar, Kalot, Great Kavir, Garmsar, Qom and Zanjan-Tasoj salt basins. Three diapiric provinces in Zagros and Persian Gulf have concerned to the Hormuz, NyrizJahrum and Shiraz-Kazerun salt basins.

Salt diapirism of Central Iran provinces can be considered as originated from function of tectonic forces, effective in the foreland basins of Central Iran. It means that tectonic processes (external trigger) are predominant compared to Halokinesis (internal trigger) in Central Iran. But, Salt diapirism of Zagros and Persian Gulf has not triggered by tectonic forces, although has affected by it. It appears that Halokinesis are predominant compared to tectonic processes in Zagros that initiated by Neogene continental collision.

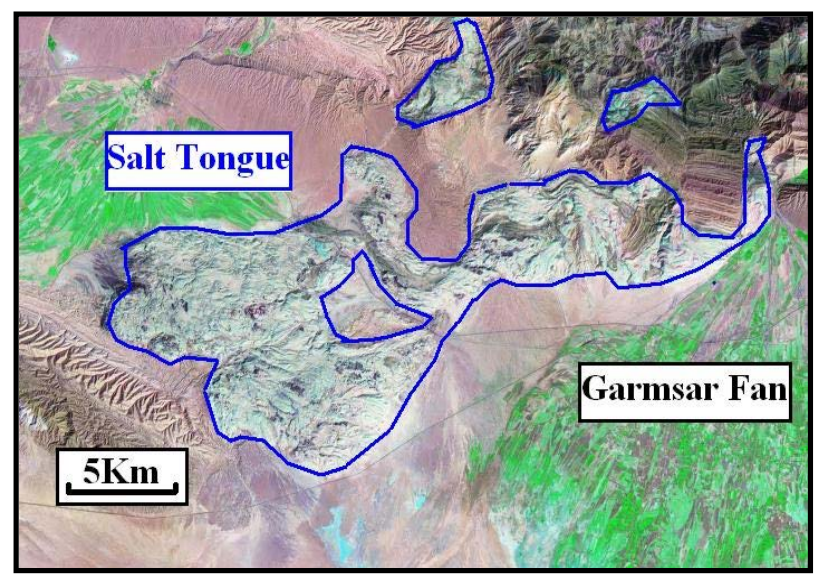

Figure 12. Interpreted ETM+ satellite image of a big salt-tongue (blue color) at Garmsar province. Map located in Figure 1. 


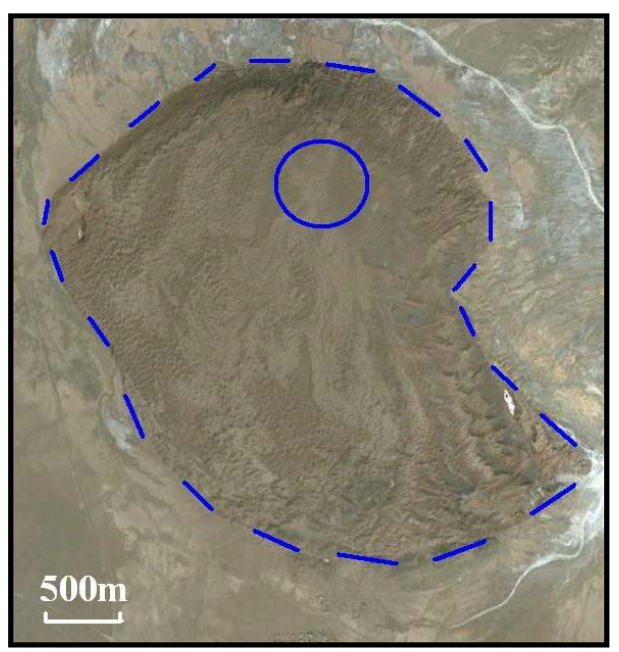

Figure 13. ETM+ Satellite image of a salt glacier (blue color) at northwest of Qom. Map located in Figure 1.

Table 1. Main characteristics of salt diapirism in the Southern Iran and Central Iran salt basins.

\begin{tabular}{|c|c|c|}
\hline Characteristics of salt diapirs & Southern Iran salt basins & Central Iran salt basins \\
\hline Age of salt diapirs & $\begin{array}{c}\text { Early Cambrian, Late } \\
\text { Triassic }\end{array}$ & $\begin{array}{l}\text { Early Cambrian, Late Jurassic, } \\
\text { Eocene-Oligocene and Miocene }\end{array}$ \\
\hline Name of diapiric formations or groups & Hormuz, Dashtak & Ravar, Mago, Lower and Upper Red \\
\hline Thickness of salt rocks & Up to $1000 \mathrm{~m}$ & Down to $1000 \mathrm{~m}$ \\
\hline Index structures & Salt Glacier and Diapiric Folds & Salt Glacier and Canopy \\
\hline Salt deposition setting & Intercontinental Rift & Intracontinental Rift \\
\hline Setting of salt diapirs evolution & Passive Margin and Collision Orogenic Belt & $\begin{array}{l}\text { Retro arc Basin and Retro } \\
\text { arc Foreland Basin }\end{array}$ \\
\hline Shape of salt diapirs & Upward Narrowing Diapirs & Columnar and Upward Widening Diapirs \\
\hline Regional shortening & Post-Diapirism & Pre \& Syn-Diapirism \\
\hline Diapirism as result of & Halokinesis & Tectonic Forces \\
\hline Freeboard elevation & to $1000 \mathrm{~m}$ & to $500 \mathrm{~m}$ \\
\hline Level of neutral buoyancy & Near to the Earth Surface & until $500 \mathrm{~m}$ Subsurface \\
\hline Overburden behavior & More Brittle & More Ductile \\
\hline Recent deformational rate & $10 \mathrm{~mm}$ per year & 2 mm per year \\
\hline Seismicity frequency & High & Low \\
\hline Folding type & Close to Open & Open to Gentle \\
\hline Salt creep rate & More & Less \\
\hline Humidity of the weather & High & Low \\
\hline Diapirs position & Determined the shape and location of folds & $\begin{array}{l}\text { Controlled by structures } \\
\text { such as faults and folds }\end{array}$ \\
\hline Number of diapiric provinces & 3 big provinces & $\begin{array}{l}6 \text { small and medium } \\
\text { provinces }\end{array}$ \\
\hline
\end{tabular}

\section{Acknowledgements}

This work has funded by the Department of Geology, Islamic Azad University, Science and Research Branch, Tehran, Iran. Also, special thanks to vice-president for research in Science and Research Branch, Tehran.

\section{References}

[1] Jackson, J.A. and Bates, R.L. (1997) Glossary of Geology. 4th Edition, American Geological Institute, Alexandria, 769 p. 
[2] Talbot, J.C. and Jackson, M.P.A. (1987) Salt Tectonics. Scientific American, Colorado, 70-79.

[3] Qorashi, M. and Arian, M. (2011) Tectonics of Iran. Geologic Survey of Iran, Tehran, 336 p. (In Persian)

[4] Arian, M. (2011) Basement Tectonics and Geology of Iran. Asar Nafis Press, Qum, 300 p. (In Persian)

[5] Motiei, H. (2001) Simplified Table of Rock Unit in South West Iran. A Map Unpublished, KEPS Company, Tehran, $234 \mathrm{p}$.

[6] Stocklin, J. (1968) Salt Deposits of the Middle East. Geological Society of America, Colorado, $181 \mathrm{p}$.

[7] Arian, M. (2013) Physiographic-Tectonic Zoning of Iran’s Sedimentary Basins. Open Journal of Geology, 3, $169-177$.

[8] Berberian, F., Muir, I.D., Pankhurst, R.J. and Berberian, M. (1982) Late Cretaceous and Early Miocene Andean-Type Plutonic Activity in Northern Makran and Central Iran. Journal of Geological Society of London, 139, 605-614. http://dx.doi.org/10.1144/gsjgs.139.5.0605

[9] Stocklin, J. (1971) Stratigraphic Lexicon of Iran Part 1: Central, North and East Iran. Geologic Survey of Iran, Tehran, $338 \mathrm{p}$.

[10] Jackson, M.P.A., Cornelius, R.R., Craig, C.H., Gansser, A., Stocklin, J. and Talbot, J.C. (1990) Salt Diapirs of the Great Kavir, Central Iran. Geological Society of America, Colorado, 139 p.

[11] Talbot, C.J., Aftabi, P. and Chemia, Z. (2009) Potash in a Salt Mushroom at Hormoz Island, Hormoz Strait, Iran. Ore Geology Reviews, 35, 317-332. http://dx.doi.org/10.1016/j.oregeorev.2008.11.005

[12] Arian, M. (2011) A Preface on Salt Diapirism of Iran. Asar Nafis Press, Qum, 309 p. (In Persian)

[13] Asadian, F. and Arian, M. (2009) Identification of Diapiric Provinces of Central Iran through Geological and Geographical Analysis. International Journal of Agriculture Environment \& Biotechnology, 2, 3443-3451.

[14] Arian, M., Ahmadnia, A., Qorashi, M. and Pourkermani, M. (2002) Structural Analysis of Mengharak Transcurrent Fault System in Zagros, Iran. Special GEO 2002 Conference Issue Geoarabia, 7, 209-210.

[15] Jahani, S., Callot, J.P., Frizon de Lamotte, D., Letouzey, J. and Leturmy, P. (2007) The Salt Diapirs of the Eastern Fars Province (Zagros, Iran): A Brief Outline of Their Past and Present. Frontiers in Earth Sciences, 2, 289-308. http://dx.doi.org/10.1007/978-3-540-69426-7_15

[16] Arian, M. (2012) Clustering of Diapiric Provinces in the Central Iran Basin. Carbonates and Evaporites, 27, 9-18. http://dx.doi.org/10.1007/s13146-011-0079-9

[17] Falcon, N. (1974) Southern Iran: Zagros Mountains. In: Spencer, A.M., Ed., Mesozoic-Cenozoic Orogenic Belts, Geological Society, London, Vol. 4, 199-211.

[18] Arian, M. (2003) Seismotectonic and Earthquake-Fault Hazard Investigations in the Kerman Region. Research Institute of Applied Sciences, Tehran, 183 p. (In Persian)

[19] Arian, M. (2010) Earthquake-Fault Hazard Investigations in the Kerman Quadrangle. Journal of Sciences (Islamic Azad University), 19, 176-182.

[20] Arian, M., Pourkermani, M., Sistanipour, A. and Noroozpour, H. (2011) Kinematic Significance of Fold- and FaultRelated Fracture Systems in the Rafsanjan's Northeast Highlands (Central Iran). Journal of Basic and Applied Scientific Research, 1, 3398-3406.

[21] Stocklin, J. (1961) Lagoonal Formations and Salt Domes in East Iran. Bulletin of Iranian Petroleum Institute, 3, 29-46.

[22] Arfa-Nia, R. (1998) Diapirism in NE Ardekan, Kalot Region. M.Sc. Dissertation, Structural Geology, Islamic Azad University, North Tehran Branch, Tehran, 230 p. (In Persian)

[23] Arian, M., Maleki, Z. and Noroozpour, H. (2011) Cenozoic Diastrophism and Deformational Events in the East-Central Alborz. Journal of Basic and Applied Scientific Research, 1, 2394-2400.

[24] Feizi, F., Arian, A. and Rahmani, R. (2007) Seismotectonic Zoning in the Eastern Part of the Central Alborz. Journal of Sciences (Islamic Azad University), 17, 151-164. (In Persian)

[25] Khavari, R., Arian, M. and Ghorashi, M. (2009) Neotectonics of the South Central Alborz Drainage Basin, in NW Tehran, N Iran. Journal of Applied Sciences, 9, 4115-4126. http://dx.doi.org/10.3923/jas.2009.4115.4126

[26] Arian, M. and Bagha, N. (2012) Active Tectonics of Tehran Area, Iran. Journal of Basic and Applied Scientific Research, 2, 3805-3819.

[27] Bagha, N., Arian, M., Ghorashi, M., Pourkermani, M., El Hamdouni, R. and Solgi, A. (2014) Evaluation of Relative Tectonic Activity in the Tehran Basin, Central Alborz, Northern Iran. Geomorphology, 213, 66-87. http://dx.doi.org/10.1016/j.geomorph.2013.12.041

[28] Talbot, C.J. and Aftabi, P. (2004) Geology and Models of Salt Extrusion at Qum Kuh, Central Iran. Journal of Geological Society, 161, 321-334. http://dx.doi.org/10.1144/0016-764903-102

[29] Pourkermani, M. and Arian, M. (2001) Structural Geomorphology of Northeastern Kurdistan, Sistan and Baluchestan 
University. Journal of Humanities, 7, 37-48.

[30] Letouzey, J., Colleta, B., Vially, R. and Chermette, J.C. (1995) Evolution of Salt Related Structures in Compressional Settings. In: Jackson, M.P.A., Roberts, D.G. and Snelson, S., Eds., Salt Tectonics: A Global Perspective, American Association of Petroleum Geologists, Tulsa, Vol. 65, 41-60.

[31] Arian, M. and Hashemi, A. (2008) Seismotectonic Zoning in the Zagros. Journal of Sciences, 18, 63-76.

[32] Arian, M., Qorashi, M., Pourkermani, M. and Ahmadnia, A. (2006) The Structural Significance Kareh Bas Transcurrent Fault System in the Zagros Fold and Thrust Belt. Journal of Geosciences, 15, 126-133. Geological Survey of Iran, Tehran. (In Persian)

[33] Hudec, M.R. and Jackson, M.P.A. (2006) Advance of Allochthonous Salt Sheets in Passive Margins and Orogens. American Association of Petroleum Geologist Bulletin, 90, 1535-1564. 